\title{
Tanggung Jawab Pribadi dalam Kasus Pungutan Liar yang Dilakukan oleh Pegawai Negeri Sipil
}

\author{
Nurmalita Ayuningtyas Harahap \\ Fakultas Hukum Universitas Islam Indonesia \\ 154101306@uii.ac.id
}

\begin{abstract}
This study analyzes about the responsibilities of civil servants (PNS) who does cases of illegal levies. The problem formulation is why do PNS who does illegal levies will be subject to personal responsibility not job responsibilities. This article concludes that violations of norms committed by PNS will incur legal consequences in the form of responsibility to the injured party. The norms that must be obeyed by civil servants in carrying out their duties are the norms of government (bestuursnorm) and norms of behavior (gedrasnorm). Accountability for violations of government norms will later be directed to government positions, with compensation imposed on agencies, with a touchstone using the principles of legality, principles of specialty, and general principles of good governance. While accountability for violations of the norms of behavior will be addressed to the relevant office holders or civil servants, with a touchstone using maladministration. Illegal levies are included in the category of maladministration, therefore in conducting maladministration which is a violation of the norms of behavior will cause legal consequences in the form of personal responsibility.
\end{abstract}

Keywords: responsibility; illegal levies; civil servants 


\begin{abstract}
Abstrak
Artikel ini membahas tentang tanggung jawab pegawai negeri sipil (PNS) yang melakukan kasus pungutan liar. Permasalahan yang dibahas adalah mengapa PNS yang melakukan pungutan liar dikenakan tanggung jawab pribadi dan bukan tanggung jawab jabatan. Artikel ini menyimpulkan bahwa pelanggaran norma yang dilakukan oleh PNS akan menimbulkan konsekuensi hukum berupa tanggung jawab kepada pihak yang dirugikan. Adapun norma yang yang harus dipatuhi pegawai negeri sipil dalam melaksanakan tugasnya adalah norma pemerintahan (bestuursnorm) dan norma perilaku (gedrasnorm). Pertanggungjawaban terhadap pelanggaran norma pemerintahan tersebut nantinya akan ditujukan kepada jabatan pemerintahan, dengan ganti rugi dibebankan kepada instansi, dengan batu uji menggunakan asas legalitas, asas spesialitas, dan asas-asas umum pemerintahan yang baik. Sedangkan pertanggungjawaban terhadap pelanggaran norma perilaku akan ditujukan kepada pemangku jabatan atau PNS yang bersangkutan, dengan batu uji menggunakan maladministrasi. Pungutan liar termasuk dalam kategori perbuatan maladministrasi, oleh karena itu dalam melakukan maladministrasi yang merupakan pelanggaran terhadap norma perilaku akan menimbulkan konsekuensi hukum berupa tanggung jawab pribadi.
\end{abstract}

Kata Kunci: tanggung jawab; pungutan liar; pegawai negeri sipil

\title{
A. Pendahuluan
}

Artikel ini membahas tanggung jawab pribadi dalam kasus pungutan liar yang dilakukan oleh Pegawai Negeri Sipil (PNS). Hal ini menarik untuk dibahas karena masih terdapat PNS yang melakukan perbuatan koruptif. Perilaku koruptif itu bisa ditemukan dalam konteks pelayanan publik. Misalnya layanan yang lamban dari PNS yang bertugas dalam administrasi kependudukan. ${ }^{1}$ Satu dari sekian perilaku koruptif yang dilakukan oleh PNS adalah tindakan pungutan liar yang menjadi bagian dari pembahasan artikel ini.

Banyaknya kasus pungutan liar atau juga dapat disebut dengan

1 https://nasional.kompas.com/read/2019/02/20/14023991/icw-lambatnya-pemecatan-pns-koruptor-akan-ciptakan-budaya-permisif, "ICW: Lambatnya Pemecatan PNS Koruptor Akan Ciptakan Budaya Permisif”, 20/2/2019, diakses 22/ $7 / 2019$. 
pungli yang dilakukan oleh oknum aparatur negara belakangan ini cukup sering menjadi temuan. Semakin banyaknya kasus pungutan liar yang dilakukan oleh, khususnya, kalangan PNS ini menjadikan salah satu indikasi bahwa perlu adanya perbaikan dalam tubuh unsur aparatur negara tersebut. Oleh karena itu dalam hal pengawasan terhadap kinerja aparatur negara, selain adanya Aparat Pengawas Internal Pemerintah, maka untuk meningkatkan pengawasan terhadap kinerja mereka dibentuklah lembaga independen, antara lain Ombudsman melalui Undang-Undang Nomor 37 Tahun 2008 tentang Ombudsman Republik Indonesia (UU Ombudsman) dan lembaga independen yang khusus mengawasi pungli, yaitu Satuan Tugas Sapu Bersih yang dibentuk pada 20 Oktober 2016 melalui Peraturan Presiden (Perpres) Nomor 87 Tahun 2016 tentang Satuan Tugas Sapu Bersih Pungutan Liar atau yang disebut dengan Satgas Saber Pungli.

Dengan pembentukan Satgas Saber Pungli tersebut, dari Tahun 2016 hingga saat ini diketahui banyak terjadi kasus pungutan liar, tidak terkecuali yang dilakukan oleh PNS sebagai unsur dari Aparatur Sipil Negara. Sejak dibentuk pada 28 Oktober 2016 hingga 23 April 2018 ini, tim Satgas Sapu Bersih Pungutan Liar (Saber Pungli) setidaknya telah menerima aduan sebanyak 35.741 laporan. ${ }^{2}$ Dari jumlah tersebut, antara lain adalah yang dilaporkan kepada tim satgas pungutan liar dari Unit Pemberantasan Pungutan Liar yang dibentuk Pemerintah Provinsi Jawa Timur, hingga pertengahan tahun 2017 lalu telah melakukan penindakan sebanyak 89 kasus. Jumlah tersangka sebanyak 175 orang, terkena operasi tangkap tangan (OTT), dengan barang bukti uang sebesar lebih kurang 3,8 miliar rupiah. Ironisnya, dari para tersangka yang terkena OTT Tim Saber Pungli, paling banyak berasal dari kalangan PNS. ${ }^{3}$ Pernyataan mengenai banyaknya

2 http://www.rri.co.id/post/berita/519506/nasional/sejak, "Sejak Dibentuk, Satgas Saber Pungli Telah Mengungkap 900 Kasus”, diakses $11 / 5 / 2018$.

3 https://www.merdeka.com/peristiwa/hingga-agustus-2017-92pns-di-jatim-jadi-tersangka-ott-pungli.html, "Hingga Agustus 2017, 92 PNS di Jatim jadi tersangka OTT pungli”, 24/8/2017, diakses $5 / 1 / 2018$. 
PNS yang menjadi tersangka OTT pungli tersebut juga terbukti dengan sebuah data yang menunjukkan bahwa sampai pada tahun 2018, masih terjadi kasus pungli yang dilakukan PNS. Diketahui pada bulan Maret, Tim Saber Pungli Polres Kuantan Singingi (Kuansing) di Riau menangkap 2 orang PNS Dinas Perhubungan (Dishub) setempat. Keduanya diduga melakukan pungli saat uji kir kendaraan. Dari 9 kendaraan yang melakukan uji KIR, ada empat pemilik kendaraan bermotor yang menjadi korban pungli kedua oknum PNS Dishub Kuansing. ${ }^{4}$ Kemudian pada pertengahan bulan ini yaitu pada bulan Juli 2018, Tim Saber Pungli Polda Sumut dikabarkan melakukan Operasi Tangkap Tangan (OTT) di Kantor Dinas Kesehatan, Kabupaten Labuhan Batu Selatan (Labusel). OTT tersebut diduga terkait dengan pungutan liar yang dilakukan terhadap dana Bantuan Operasional Kesehatan (BOK) tahun anggaran 2018. ${ }^{5}$

Sebagai aparat pemerintah yang tidak lepas dari jabatan dan kewenangan, seorang PNS dalam menjalankan tugas dan fungsinya harus memperhatikan norma pemerintahan (bestuursnorm) dan norma perilaku (gedragsnorm). Pelanggaran atas norma pemerintahan dan norma perilaku tersebut akan memiliki konsekuensi pada tanggung jawab yang harus dipikul oleh pegawai negeri sipil. Tanggung jawab inilah yang kemudian disebut sebagai jawab jabatan atau tanggung jawab pribadi. ${ }^{6}$ Adapun berkaitan dengan kasus pungutan liar tersebut, maka dapat dikatakan terdapat norma-norma yang tidak ditaati oleh PNS dalam menjalankan tugas dan fungsinya, yang kemudian ketidaktaatan pada norma tersebut akan berakibat PNS tersebut dikenakan tanggung jawab. Secara teoritik, apabila membicarakan tentang tanggung jawab PNS, maka tanggung jawab yang

4 https://news.detik.com/ berita/d-4009243/pungli-kir-2-pns-dishub-diriau-kena-ott-tim-saber, "Pungli KIR, 2 PNS Dishub di Riau Kena OTT Tim Saber", 7/5/2018, diakses 8/5/2018.

5 https: / / medan.tribunnews.com/2018/07/11/tim-saber-pungli-lakukanott-di-dinkes-labusel, “Tim Saber Pungli Lakukan OTT di Dinkes Labusel”, $11 / 7 / 2018$, diakses $21 / 7 / 2018$.

6 Ridwan H.R, "Catatan Ringkas Hukum Kepegawaian”, Bahan Perkuliahan Hukum Kepegawaian di Fakultas Hukum Universitas Islam Indonesia, Yogyakarta, 2018, hlm. 20. 
dikenakan kepada PNS tersebut adalah tanggung jawab pribadi bukan tanggung jawab jabatan. ${ }^{7}$ Oleh karena yang dikenakan adalah tanggung jawab pribadi, maka pertanyaan dasar yang menjadi bagian dari ruang lingkup artikel ini adalah mengapa PNS yang melakukan pungutan liar akan dikenakan tanggung jawab pribadi bukan tanggung jawab jabatan.

\section{B. Tinjauan Umum tentang Maladministrasi}

Permasalahan hukum yang selalu terkait dengan penyelenggaraan pemerintahan adalah masalah maladministrasi. Maladministrasi adalah perilaku yang tidak wajar (termasuk penundaan pemberi pelayanan), tidak sopan dan kurang peduli terhadap masalah yang menimpa seseorang disebabkan oleh perbuatan penyalahgunaan kekuasaan, termasuk penggunaan kekuasaan secara semena-mena atau kekuasaan yang digunakan untuk perbuatan yang tidak wajar, tidak adil, intimidatif, atau diskriminatif dan tidak patut didasarkan sebagian atau seluruhnya atas ketentuan undang-undang atau fakta, serta tidak masuk akal. ${ }^{8}$

Maladministrasi berasal dari bahasa Latin malum, yang berarti jahat, buruk, jelek, dan administrare, yang berarti mengurus atau melayani; sehingga maladministrasi berarti pelayanan atau pengurusan yang buruk atau jelek. Maladministrasi adalah suatu praktik yang menyimpang dari etika administrasi, atau suatu praktik administrasi yang menjauhkan dari pencapaian tujuan administrasi. ${ }^{9}$ Pasal 1 butir 3 dalam UU Ombudsman menyebutkan:

"Maladministrasi adalah perilaku atau perbuatan melawan hukum, melampaui wewenang, menggunakan wewenang untuk tujuan lain dari yang menjadi wewenang tersebut, termasuk kelalaian atau pengabaian kewajiban hukum dalam penyelenggaraan pelayanan publik yang dilakukan oleh Penyelenggara Negara dan pemerintahan, termasuk perseorangan yang membantu pemerintah memberikan pelayanan publik yang menimbulkan kerugian materiil dan/atau imateriil bagi masyarakat

7 Ridwan H.R, "Catatan Ringkas Hukum Kepegawaian”, hlm. 20.

8 Tedi Sudrajat, Hukum Birokrasi Pemerintah Kewenangan dan Jabatan (Jakarta: Sinar Grafika, 2017), hlm. 185.

9 Joko Widodo, Good Governance (Surabaya: Insan Cendikia, 2001), hlm. 259. 
dan orang perseorangan."

Hadjon menyatakan bahwa, maladministrasi dimaknai sebagai perilaku yang tidak wajar (termasuk penundaan pemberi pelayanan), tidak sopan dan kurang peduli terhadap masalah yang menimpa seseorang disebabkan oleh perbuatan penyalahgunaan kekuasaan, termasuk penggunaan kekuasaan secara semena-mena atau kekuasaan yang digunakan untuk perbuatan yang tidak wajar, tidak adil, intimidatif atau diskriminatif dan tidak patut didasarkan sebagian atau seluruhnya atas ketentuan undang-undang atau fakta, serta tidak masuk akal. ${ }^{10}$

Adapun bentuk-bentuk maladminstrasi yang paling umum antara lain penundaan berlarut, penyalahgunaan wewenang, penyimpangan prosedur, pengabaian kewajiban hukum, tidak transparan, kelalaian, diskriminasi, tidak profesional, ketidakjelasan informasi, tindakan sewenang-wenang, ketidakpastian hukum, salah pengelolaan. ${ }^{11}$ Ketentuan-ketentuan tentang bentuk maladministrasi itu memang tidak disebutkan secara literal (secara langsung) sebagai maladministrasi. Ketentuan-ketentuan tentang bentuk maladministrasi yang tersebar di dalam berbagai undang-undang lebih lanjut hanya dikaitkan dengan tugas pokok dan fungsi kelembagaan yang menjadi penyelenggara pelayanan publik. Adapun landasan hukum yang langsung menyebut tentang pencegahan dan penyelesaian maladministrasi adalah UU Ombudsman dan Undang-Undang Nomor 25 Tahun 2009 tentang Pelayanan Publik (UU Pelayanan Publik).

Selain dijelaskan mengenai pengertian maladministrasi, maka sekiranya perlu untuk dijabarkan pula mengenai perbuatan yang dikategorikan sebagai bentuk dari perbuatan maladministrasi. Termasuk bentuk tindakan maladministrasi adalah tindakan-tindakan yang

10 Tedi Sudrajat, Perlindungan Hukum Atas Biropatologi yang Berimplikasi Maladministrasi: Analisis Tindakan Penundaan Berlarut dalam Proses Perizinan, Civil Service: Jurnal Kebijakan dan Manajemen PNS, 12, 2 (2018): 173-181.

11 Ombudsman Republik Indonesia(ORI), Memahami Maladministrasi (Jakarta: Ombudsman RI, 2013), hlm. 5. 
dilakukan aparatur pemerintah dikarenakan adanya, pertama, mis conduct atau kesalahan, yaitu melakukan sesuatu di kantor yang bertentangan dengan kepentingan kantor. Kedua, deceitful practice, yaitu praktik-praktik kebohongan, tidak jujur terhadap publik. Ketiga, adanya korupsi yang terjadi karena penyalahgunaan wewenang yang dimilikinya. Keempat, adanya defective policy implementation, yaitu kebijakan yang tidak berakhir dengan implementasi. Selain itu juga terdapat penyakit-penyakit birokrasi yang masih dilikukan di lingkungan PNS tersebut bekerja. Penyakit-penyakit ini antara lain indecision yang dapat diartikan bahwa tidak adanya keputusan yang jelas atas suatu kasus. Jadi suatu kasus yang pernah terjadi dibiarkan setengah jalan, atau dibiarkan mengambang, tanpa ada keputusan akhir yang jelas. Kelima, red tape, yaitu penyakit birokrasi yang berkaitan dengan penyelenggaraan pelayanan yang berbelitbelit, memakan waktu lama, meski sebenarnya bisa diselesaikan secara singkat. Keenam, psycophancy, yaitu kecenderungan penyakit birokrat untuk "menjilat" pada atasannya, sehingga ada gejala "asal bapak senang”. Selain itu terdapat beberapa sikap lainnya seperti pembangkangan terhadapat staf, kecenderungan birokrasi menggunakan banyak kertas, banyak formulir-formulir, banyak laporanlaporan, tetapi tidak pernah dipergunakan sebagaimana mestinya fungsinya, dan pemeriksaan keuangan yang cacat, yang termasuk penyakit birokrasi. ${ }^{12}$

Bentuk-bentuk maladministrasi yang terkait dengan ketepatan waktu dalam proses pemberian pelayanan umum, terdiri dari tindakan penundaan berlarut, tidak menangani dan melalaikan kewajiban. ${ }^{13}$ Bentuk-bentuk maladministrasi yang mencerminkan keberpihakan sehingga menimbulkan rasaketidakadilandandiskriminasi. Kelompok ini terdiri dari persekongkolan, kolusi dan nepotisme, bertindak tidak adil, dan nyata-nyata berpihak. ${ }^{14}$ Bentuk-bentuk maladministrasi yang lebih mencerminkan sebagai bentuk pelanggaran terhadap hukum

12 Ridwan H.R dan Nurmalita Ayuningtyas Harahap, Hukum Kepegawaian (Yogyakarta: UII Press, 2018), hlm. 145-146.

13 Ridwan H.R dan Harahap, Hukum Kepegawaian, hlm. 147.

14 ORI, Memahami Maladministrasi, hlm. 15. 
dan peraturan perundangan. Kelompok ini terdiri dari pemalsuan, pelanggaran undang-undang, dan perbuatan melawan hukum. ${ }^{15}$

Bentuk-bentuk maladministrasi yang terkait dengan kewenangan/kompetensi atau ketentuan yang berdampak pada kualitas pelayanan umum pejabat publik kepada masyarakat, terdiri dari tindakan diluar kompetensi, pejabat yang tidak kompeten menjalankan tugas, intervensi yang mempengaruhi proses pemberian pelayanan umum, dan tindakan yang menyimpangi prosudur tetap. ${ }^{16}$ Adapun yang sering kali dilakukan pula oleh aparat pemerintah dalam penyelenggaraan pelayanan publik adalah bentuk-bentuk maladministrasi yang mencerminkan sebagai bentuk korupsi secara aktif. Kelompok ini terdiri dari tindakan pemerasan atau permintaan imbalan uang (korupsi), tindakan penguasaan barang orang lain tanpa hak, dan penggelapan barang bukti, yang dapat dijelaksan, yaitu pertama, permintaan imbalan uang/korupsi dalam proses pemberian pelayanan umum kepada masyarakat, seorang pejabat publik meminta imbalan uang dan sebagainya atas pekerjaan yang sudah semestinya dia lakukan secara cuma-cuma karena merupakan tanggung jawabnya atau seorang pejabat publik menggelapkan uang negara, badan usaha milik negara/ daerah dan sebagainya untuk kepentingan pribadi atau orang lain sehingga menyebabkan pelayanan umum tidak dapat diberikan kepada masyarakat secara baik. Kemudian yang kedua, penguasaan tanpa hak, yaitu seorang pejabat publik memenguasai sesuatu yang bukan milik atau kepunyaannya secara melawan hak, padahal semestinya sesuatu tersebut menjadi bagian dari kewajiban pelayanan umum yang harus diberikan kepada masyarakat, dan kemudian yang terakhir adalah penggelapan barang bukti, yaitu seorang pejabat publik terkait dengan proses penegakan hukum telah menggunakan barang, uang dan sebagainya secara tidak sah, yang merupakan alat bukti suatu perkara. Akibatnya, ketika pihak yang berperkara meminta barang bukti tersebut (misalkan setelah tuduhan tidak terbukti) pejabat publik terkait tidak dapat memenuhi

15 ORI, Memahami Maladministrasi, hlm. 15-16.

16 Ridwan H.R dan Harahap, Hukum Kepegawaian, hlm. 149. 
kewajibannya. ${ }^{17}$

Berkenaan dengan bentuk maladministrasi yang dilakukan oleh Pegawai Negeri Sipil, dalam Pasal 4 Peraturan Pemerintah Nomor 53 Tahun 2010 tentang Disiplin Pegawai Negeri Sipil dimuat rincian larangan-larangan yang tidak boleh dilanggar oleh PNS. Semua ketentuan dan larangan tersebut jika dilakukan oleh pejabat dan/ atau pegawai publik, akan tergolong tindakan maladministrasi.

\section{Pertanggungjawaban Pegawai Negeri Sipil}

Pegawai negeri sipil sebagai aparatur negara bertugas membantu presiden sebagai kepala pemerintahan dalam menyelenggarakan pemerintahan, tugas melaksanakan peraturan perundang-undangan, dalam arti kata wajib menguasahakan agar setiap peraturan perundang-undangan ditaati oleh masyarakat. Dalam melaksanakan peraturan perundangan pada umumnya, pegawai negeri diberikan tugas kedinasan untuk dilaksanakan dengan sebaik-baiknya. ${ }^{18}$ Dengan demikian maka PNS sebagai aparatur negara, yang berarti juga termasuk organ pemerintahan dalam melaksanakan tugasnya yang berdasarkan dengan apa yang terdapat pada peraturan perundangundangan sangat berhubungan erat dengan asas legalitas. Sebagai salah satu prinsip negara hukum, asas legalitas mengandung makna bahwa setiap tindakan hukum pemerintahan harus berdasarkan pada peraturan perundang-undangan yang berlaku atau setiap tindakan hukum pemerintah harus berdasarkan pada kewenangan yang diberikan oleh peraturan perundang-undangan. ${ }^{19}$ Dalam suatu negara hukum, setiap tindakan jabatan yang dilakukan oleh satu perwakilan (vertegenwoordiger) yaitu pejabat (ambtsdrager), harus berdasarkan pada asas legalitas. ${ }^{20}$

Bersandar pada asas legalitas itulah pemerintah kemudian

17 ORI, Memahami Maladministrasi, hlm. 17-18.

18 Rozali Abdullah, Hukum Kepegawaian (Jakarta: Rajawali, 1986), hlm. 18.

19 Ridwan H.R, Hukum Administrasi Negara (Jakarta: Rajawali Pers, 2016), hlm. 339.

20 Ridwan H.R, Hukum Administrasi di Daerah (Yogyakarta: FH UII Press, 2009), hlm. 114. 
melakukan berbagai tindakan hukum berdasarkan kewenangan. Dalam negara hukum, wewenang pemerintahan itu berasal dari peraturan perundang-undangan yang berlaku, artinya sumber wewenang bagi pemerintah atau dalam hal ini termasuk pegawai negeri sipil adalah peraturan perundang-undangan. Adapun terkait dengan suatu prinsip negara hukum, tindakan pemerintah yang harus didasarkan atas kewenangan yang diberikan oleh peraturan perundang-undangan, maka perlu sekiranya diketahui mengenai sumber atau cara pemerintah dalam memperoleh wewenang. Secara teoritis, kewenangan yang bersumber dari peraturan perundangundangan diperoleh melalui tiga cara, yakni atribusi, delegasi dan mandat. H.D. van Wijk dalam Ridwan H.R. mendefinisikan atribusi (attributie) adalah pemberian wewenang pemerintahan oleh pembuat undang-undang kepada organ pemerintahan; delegasi (elegatie)adalah pelimpahan wewenang pemerintahan dari satu organ pemerintahan kepada organ pemerintahan lainnya; mandat (mandaat) adalah terjadi ketika organ pemerintahan mengizinkan kewenangannya dijalankan oleh organ lain atas namanya. ${ }^{21}$

Dari penjelasan ketiga cara memperoleh kewenangan tersebut, dapat dijabarkan kembali bahwa wewenang yang diperoleh secara atribusi itu bersifat asli dan diperoleh dari peraturan perundangundangan. Dengan kata lain, organ pemerintahan memperoleh kewenangan secara langsung dari redaksi pasal tertentu dalam suatu peraturan perundang-undangan. Dalam hal atribusi, penerima wewenang dapat menciptakan wewenang baru atau memperluas wewenang yang sudah ada dengan tanggung jawab intern dan ekstern pelaksanaan wewenang yang di atribusikan sepenuhnya berada pada penerima wewenang (atributaris). ${ }^{22}$

Pada delegasi sesungguhnya tidak ada penciptaan wewenang, yang ada hanya pelimpahan wewenang dari pejabat yang satu kepada pejabat yang lainnya. Tanggung jawab yuridis tidak lagi berada pada pemberi delegasi (delegans), tetapi beralih pada penerima delegasi

21 Ridwan H.R, Hukum Administrasi di Daerah, hlm. 102.

22 Ridwan H.R, Hukum Administrasi Negara, hlm. 105. 
(delegataris). ${ }^{23}$ Dalam delegasi terdapat hubungan horizontal bukan pejabat yang sifatnya internal, yaitu atasan dan bawahan, antara pejabat yang melimpahkan wewenang kepada pejabat yang menerima wewenang. Dasar hukum pemberian delegasi ini harus secara tegas disebutkan di dalam peraturan di mana kewenangan pemerintahan berada, atau di dalam delegasi umum. ${ }^{24}$ Sementara pada mandat, penerima mandat (mandataris) hanya bertindak untuk dan atas nama pemberi mandat (mandans), tanggung jawab akhir keputusan yang diambil mandataris tetap berada pada mandans. ${ }^{25}$ Berbeda dengan delegasi, mandat terjadi pada pejabat yang sifatnya internal yaitu atasan dan bawahan, sebagai contoh menteri dan pegawainya. Hal ini juga sering berlaku dalam hukum kepegawaian. ${ }^{26}$

Dengan ketiga cara itulah maka pemerintah atau PNS dapat memperoleh kewenangannya. Pemberian wewenang tertentu untuk melakukan tindakan hukum tertentu akan menimbulkan pertanggungjawaban atas penggunaan wewenang tersebut. ${ }^{27}$ Karena wewenang itu melekat pada jabatan namun dalam implementasinya dijalankan oleh manusia selaku wakil atau fungsionaris jabatan, maka siapa yang harus memikul tanggung jawab hukum ketika terjadi penyimpangan harus dilihat secara kasuistik dikarenakan tanggung jawab itu dapat berupa tanggung jawab jabatan dan dapat pula berupa tanggung jawab dan tanggung gugat pribadi. ${ }^{28}$ Sri Soemantri mengemukakan bahwa setiap pemberian kewenangan kepada pejabat pemerintah tersirat adanya kewenangan pertanggungjawaban, sesuai prinsip "geen bevoegdheid zonder verantwoordelijkheid" (tidak ada kewenangan atau kekuasaan tanpa pertanggungjawaban). ${ }^{29}$

Tanggung jawab adalah keadaan wajib menanggung segala

23 Ridwan H.R, Hukum Administrasi Negara, hlm. 105.

24 S.F. Marbun, Hukum Administrasi Negara I (Yogyakarta: UII Press, 2012), hlm. 77.

25 S.F. Marbun, Hukum Administrasi Negara I, hlm. 105-106.

26 Ridwan H.R, Hukum Administrasi Negara, hlm. 103.

27 Ridwan H.R, Hukum Administrasi di Daerah, hlm. 115.

28 Ridwan, Diskresi dan Tanggung Jawab Pemerintah (Yogyakarta: FH UII Press, 2014), hlm. 190.

29 Ridwan H.R, Hukum Administrasi Negara, hlm. 103. 
sesuatunya (kalau ada sesuatu hal, boleh dituntut, dipersalahkan, diperkarakan, dan sebagainya), dengan kata lain, "aansprkelijk, verplicht tot het afleggen van verantwoording en tot het dragen van event, toerenkenbare schade (desgevorderd), in rechts of in bestuursverband" (tanggung jawab adalah kewajiban memikul pertanggungjawaban dan memilikul kerugian yang diderita [bila dituntut], baik dalam hukum maupun dalam administrasi). ${ }^{30}$ Mengenai persoalan pertanggungjawaban pemerintah atau pejabat, menurut Kranenburg dan Vegtig ada dua teori yang melandasinya yaitu, pertama, teori fautes personalles, merupakan teori yang menyatakan bahwa kerugian terhadap pihak ketiga dibebankan kepada pejabat yang karena tindakannya itu telah menimbulkan kerugian. Dalam teori ini beban tanggung jawab ditujukan pada manusia selaku pribadi. Kedua, eori fautes de services, yaitu teori yang menyatakan bahwa kerugian terhadap pihak ketiga dibebankan pada instansi dari pejabat yang bersangkutan. Menurut teori ini tanggung jawab dibebankan kepada jabatan. Dalam penerapannya, kerugian yang timbul itu disesuaikan pula apakah kesalahan yang dilakukan itu merupakan kesalahan berat atau kesalahan ringan, di mana berat dan ringannya suatu kesalahan berimplikasi pada tanggung jawab yang harus ditanggung. ${ }^{31}$

Berbicara mengenai pertanggungjawaban pemerintah atau dalam hal ini PNS, maka perlu diketahui pula mengenai normanorma yang harus ditaati dalam melaksanakan tindakan hukum dalam kewenangannya. Dalam perspektif Hukum Tata Negara dan Hukum Administrasi, ada dua entitas penyelenggaraan urusan pemerintahan yang dapat dibedakan namun tidak dapat dipisahkan satu dengan yang lainnya, yakni jabatan dan pemangku jabatan atau pejabat. Berkenaan dengan dua entitas tersebut, dikenal adanya dua jenis norma, yaitu norma pemerintahan (bestuursnorm) dan norma perilaku aparat (gedragsnorm). ${ }^{32}$ Norma pemerintahan adalah kaidahkaidah hukum tertulis dan tidak tertulis yang berlaku dan diterapkan terhadap jabatan pemerintahan, sedangkan norma perilaku meru-

30 Ridwan H.R, Hukum Administrasi di Daerah, hlm. 115.

31 Ridwan H.R, Hukum Administrasi Negara, hlm. 345-346.

32 Ridwan H.R, Diskresi dan Tanggung Jawab Pemerintah, hlm. 190. 
pakan kaidah-kaidah hukum tertulis dan tidak tertulis yang harus diperhatikan dan dipatuhi oleh pemangku jabatan. ${ }^{33}$ F.C.M.A Michiels menyebutkan bahwa, "er zijn naast rechtmatigheidsnormen ook fatsoensnormen. Schending daarvaan is incorrect, naar niet onrechtmatig" (di samping ada norma keabsahan juga terdapat norma kesopanan. Pelanggaran terhadap norma kesopanan tidaklah dibenarkan, tetapi tidak dikategorikan sebagai perbuatan melanggar hukum). ${ }^{34}$

Keharusan memperhatikan dan mematuhi norma pemerintahan dan norma perilaku ini terutama karena asas negara hukum yang menghendaki agar penggunaan wewenang itu berjalan sesuai dengan hukum dan tidak melanggar hak-hak warga negara. P.M.B Schrijvers dan H.C.N. Smeets mengatakan, "overheidsorganen nemen bij het uitoefenen van bestuurstaken vaak een monopoliepositie in. Daarom moeten de grenzen van hun bevoegdheden en de rechtsbeschreming tegen een onjuist gebruik ervan door het bestuursrecht zo nauwkeurig mogelijk worden gesteld" (organ-organ pemerintahan dalam melaksanakan tugas-tugas dan kewenangannya memiliki kedudukan monopoli, karena itu harus diatur secermat mungkin melalui hukum administrasi mengenai batas-batas dalam penggunaan kewenangannya dan mengenai perlindungan hukum dari perbuatan pemerintah yang menyimpang). Secara singkat, Sir William Wade dan Christopher Forysth menulis, "the primary purpose of administrative law, therefore, is to keep the powers of government within their bounds, so as to protect the citizen against their ebuse" (tujuan utama hukum administrasi adalah menjaga kekuasaan pemerintah dalam batas-batasnya, untuk melindungi warga negara dari penyalagunaan kekuasaan). ${ }^{35}$

Berkenaan dengan norma pemerintahan dan norma perilaku aparat pemerintah tersebut, patut pula dikemukakan pendapat J.H.J. van den Hauvel yang mengatakan bahwa ada tiga prinsip yang harus dipenuhi untuk penyelenggaraan urusan pemerintahan, yaitu prinsip legalitas (legaliteid), legitimasi (legitimiteit), dan integritas (integriteit). ${ }^{36}$

33 Ridwan H.R, “Catatan Ringkas Hukum Kepegawaian”, hlm. 20.

34 Ridwan H.R, Diskresi dan Tanggung Jawab Pemerintah, hlm. 190.

35 Ridwan H.R dan Harahap, Hukum Kepegawaian, hlm. 157.

36 Ridwan H.R, Diskresi dan Tanggung Jawab Pemerintah, hlm. 192. 
Keharusan memperhatikan dan mematuhi norma pemerintahan dan norma perilaku juga relevan dengan kenyataan bahwa pejabat dan para pegawai adalah manusia selaku makhluk yang bersifat ruhani dan jasmani (geestelijk tevens stoffelijk wezen), yang dalam melakukan tindakan atau menggunakan wewenang, dipengaruhi oleh berbagai faktor dan kepentingan atau ada unsur subyektifitas pejabat yang bersangkutan, sehingga dimungkinkan adanya penyimpangan dalam penggunaan wewenang. Kewajiban memikul tanggung jawab dan tanggung gugat bagi organ pemerintah berjalan paralel dengan lahirnya hak gugat bagi warga negara yang dirugikan. ${ }^{37}$

Sehubungan bahwa dua entitas tersebut di atas tidak dapat dipisahkan dalam penyelenggaraan urusan pemerintahan, sehingga tanggung jawab dan tanggung gugat juga mencakup dua hal yakni tanggung jawab dan tanggung gugat jabatan dan pribadi J.H.A. Logemann yang mengatakan bahwa, "het ambt wordt vertegenwoordigd door de ambtsdrager. Dit betekent niet allen de toerekening van kwade trouw, wetenschap" (jabatan diwakili oleh pejabat. Ini berarti bukan hanya pertanggungjawaban tindakan jabatan yang dilakukan, tetapi juga unsur psikis seperti kesesatan, iktikad buruk, dan pengetahuan). ${ }^{38}$ Tanggung jawab jabatan berkenan dengan keabsahan tindakan hukum pemerintahan yang dilakukan oleh pejabat untuk dan atas nama jabatan (ambtshalve). Menurut F.R. Bothlingk, baik wakil maupun yang diwakili adalah pelaku, namun tidak berarti bahwa keduanya mempunyai tanggung jawab. Berkenan dengan perbuatan hukum, jawabannya jelas. Perbuatan hukum adalah pernyataan kehendak dan tanggung jawab secara khusus tertuju kepada pihak yang kehendaknya dinyatakan, yakni pihak yang diwakili. Wakil tidak menyatakan kehendaknya sendiri, karena itu meletakan tanggung jawab kepadanya tidak pada tempatnya. ${ }^{39}$

Berdasarkan keterangan tersebut, maka pemikul tanggung

37 Ridwan H.R, Diskresi dan Tanggung Jawab Pemerintah, hlm. 193.

38 Ridwan H.R dan Harahap, Hukum Kepegawaian, hlm. 153.

39 Sufriadi, "Tanggung Jawab Jabatan dan Tanggung Jawab Pribadi dalam Penyelenggaraan Pemerintahan di Indonesia”, Jurnal Yuridis, 1, 1 (2014), hlm. 69. 
jawab itu adalah jabatan. Oleh karena itu, ganti rugi juga dibebankan kepada instansi/jabatan, bukan kepada pejabat selaku pribadi. Sebagai contoh, dapat ditujukkan ketentuan yang tercantum dalam Pasal 2 ayat (1) dan (2) Peraturan Pemerintah Nomor 43 Tahun 1991 tentang Ganti Rugi dan Tata Cara Pelaksanaannya pada Pengadilan Tata Usaha Negara, bahwa, "ganti rugi yang menjadi tanggung jawab Badan Tata Usaha Negara Pusat, dibebankan pada Anggaran Pendapatan dan Belanja Negara (APBN), dan "ganti rugi yang menjadi tanggung jawab Badan Tata Usaha Negara Daerah, dibebankan pada Anggaran Pendapatan dan Belanja Daerah (APBD)". Dengan demikian, jelaslah bahwa pemikul tanggung jawab dan beban kerugian itu berada dan ditanggung oleh jabatan atau instansi di mana pejabat yang bersangkutan berada, bukan oleh pejabat sebagai pribadi. ${ }^{40}$

Di sisi lain, meskipun kewenangan itu melekat pada jabatan yang membawa konsekuensi melekatnya tanggung jawab pada jabatan yang bersangkutan, dalam pelaksanaan kewenangan itu dapat saja tanggung jawabnya dibebankan kepada pribadi (in persoon) pejabat. Tanggung jawab pribadi berkaitan dengan maladministrasi dalam penggunaan wewenang maupun public service. Seorang pejabat yang melaksanakan tugas dan kewenangan jabatan atau membuat kebijakan akan dibebani tanggung jawab pribadi jika ia melakukan tindakan maladministrasi. F.R. Bothlingk mengatakan bahwa pejabat atau wakil itu bertanggung jawab sepenuhnya, ketika ia menyalahgunakan situasi dengan melakukan tindakan amoralnya sendiri terhadap kepentingan pihak ketiga. ${ }^{41}$ Terkait dengan pelanggaran terhadap norma pemerintahan akan menimbulkan konsekuensi tanggung jawab jabatan dan pelanggaran norma perilaku aparat pemerintah akan menimbulkan konsekuensi tanggung jawab pribadi, tanggung jawab itu akan berubah menjadi tanggung jawab pribadi jika di dalammnya terdapat kesalahan pribadi yakni dalam bentuk maladministrasi. ${ }^{42}$

40 Ridwan H.R, Hukum Administrasi Negara, hlm. 348.

41 Ridwan H.R, Hukum Administrasi Negara, hlm. 348.

42 Ridwan H.R, "Catatan Ringkas Hukum Kepegawaian”, hlm. 21. 


\section{Tanggung Jawab Pribadi bagi Pegawai Negeri Sipil dalam Kasus Pungutan Liar}

Secara filosofis, tujuan dibentuknya Pemerintah Negara Indonesia adalah untuk menciptakan ketetraman dan ketertiban (law and order) dan kesejahteraan (welfare). Hal ini sebaimana termaktub dalam Pembukaan Undang-Undang Dasar Negara Republik Indonesia (UUDNRI 1945), yaitu, "Kemudian dari pada itu untuk membentuk suatu Pemerintah Negara Indonesia yang melindungi segenap bangsa Indonesia dan seluruh tumpah darah Indonesia dan untuk memajukan kesejateraan umum, mencerdaskan kehidupan bangsa, dan ikut melaksanakan ketertiban dunia yang berdasarkan kemerdekaan, perdamaian abadi dan keadilan sosial...”. Untuk mewujudkan tujuan tersebut dibutuhkan pegawai yang memiliki kompetensi dan kepribadian sehingga kinerja pegawai dapat optimal. ${ }^{43}$ Pegawai tersebut disebut dengan PNS atau yang kini termasuk Aparatur Sipil Negara (ASN).

Pegawai negeri berkedudukan sebagai unsur aparatur negara yang bertugas untuk memberikan pelayanan kepada masyarakat secara profesional, jujur, adil dan merata dalam penyelenggaraan tugas negara, pemerintahan dan pembangunan. ${ }^{44}$ PNS sebagai aparatur negara adalah abdi negara dan abdi masyarakat. Sebagai abdi negara, seorang pegawai negeri terikat dengan segala aturan hukum. Nilai-nilai etika yang harus ditaati oleh PNS tercermin dalam kewajiban PNS berdasarkan peraturan perundang-undangan. Bentuk kewajiban tersebut terakumulasi dalam bentuk sikap dan perilaku yang harus dijaga oleh setiap PNS. ${ }^{45}$ Kedudukan dan peranan Pegawai Negeri Sipil (PNS) sangat penting dan menentukan bagi negara, karena pegawai negeri sipil adalah unsur aparatur negara,

43 Randy Saputra, "Pengaruh disiplin kerja, Reward dan Punishment terhadap Kinerja Pegawai (Studi Kasus Direktorat Jenderal Bina Keuangan Daerah Kementerian dalam Negeri)", Civil Service: Jurnal Kebijakan dan Manajemen PNS, 10, 2 (2016): 55-69.

44 S.F. Marbun, Hukum Administrasi Negara I, hlm. 186.

45 Sri Hartini dan Tedi Sudrajat, Hukum Kepegawaian di Indonesia (Jakarta: Sinar Grafika, edisi kedua, 2017), hlm. 52. 
abdi negara sekaligus abdi masyarakat untuk menyelenggarakan pemerintahan dan pembangunan dalam rangka mencapai tujuan nasional. Peningkatan kualitas PNS akan dapat dilihat dari kinerja pegawai dalam melaksanakan tugas dan peran yang diembannya sesuai dengan tuntutan organisasi atau lembaga, oleh karena itu upaya mengelola dan mengembangkan kinerja individu dalam organisasi menjadi hal yang sangat pentingdalam membangun dan mengembangkan kemampuan organisasi untuk dapat berperan optimal dalam masyarakat. ${ }^{46}$ Berhasil dan tidaknya pemerintah dalam menjalankan roda pemerintahan, sangatlah tergantung pada profesionalisme PNS yang merupakan bagian dari ASN tersebut, karena PNS merupakan modal bangsa dan negara yang harus dijaga dan dibina. ${ }^{47}$

PNS yang secara normatif merupakan ASN, sebagaimana yang tercantum dalam peraturan perundang-undangan yang secara khusus mengaturnya yaitu Undang-Undang Nomot 5 Tahun 2014 tentang Aparatur Sipil Negara (UU ASN), merupakan merupakan salah satu faktor dalam terciptanya peningkatan pelayanan publik. Oleh karena aparat pemerintah merupakan unsur yang bekerja di dalam praktik untuk memberikan pelayanan kepada masyarakat, maka secara sosiologis mereka mempunyai kedudukan atau peranan dalam terciptanya suatu pelayanan publik yang maksimal..$^{48}$

Namun pada kenyataanya sebagian PNS belum dapat menjalakan kedudukannya sebagai aparatur negara yang profesional, jujur, dan menerapkan etika-etika dalam kewajibannya sebagaimana yang diatur dalam peraturan perundang-undangan khususnya dalam hal melakukan pelayanan publik, yang merupakan tugas utama dari seorang PNS. Perilaku dan etika yang menyimpang ini dapat tercermin

46 Novia Cahyaningrum, Andre N. Rahmanto, Tutik Susilowati, "Pembinaan Kinerja Pegawai Negeri Sipil di Dinas Pendidikan Kota Surakarta”, Jurnal Informasi dan Komunikasi Administrasi Perkantoran, 2, 2 (2018): 63-78.

47 Ajib Rakhmawanto, "Analisis Model Pembinaan Jabatan Fungsional Analisis Kepegawaian di Badan Kepegawaian Negara”, Civil Service: Jurnal Kebijakan dan Manajemen PNS, 10, 1 (2016): 1-14.

48 Juniarso Ridwan dan Achmad Sodik Sudrajat, Hukum Administrasi Negara dan Kebijakan Pelayanan Publik (Bandung: Nuansa, 2009), hlm. 22. 
dari maraknya kasus pungutan liar atau pungli yang dilakukan oleh oknum PNS yang sampai saat ini masih sering terjadi, seperti kasus yang telah dijabarkan pada bagian latar belakang masalah. Maka sekiranya perlu adanya analisis megenai praktik pungutan liar yang dilakukan oleh oknum PNS dari perspektif hukum administrasi negara terkait dengan teori tanggung jawab yang akan dikenakan pada oknum PNS tersebut.

Mengenai kasus pungutan liar yang dilakukan oleh PNS, maka hendaknya perlu diketahui lebih jelas mengenai subjek hukum yang melakukan pungutan liar tersebut. Tentunya dalam hal ini yang melakukan adalah oknum PNS. Pegawai negeri adalah mereka yang menjalankan tugas pekerjaan negara dan pemerintah atau mereka yang bekerja melayani kepentingan publik yang merupakan fungsi negara dan pemerintah, ${ }^{49}$ yang berarti PNS selalu dikaitkan dengan jabatan yang melaksanakan tugas dan fungsinya sesuai dengan peraturan perundang-undangan. Dalam hal ini berarti PNS merupakan subjek hukum yang dilekati kewenangan yang diberikan oleh peraturan perundang-undangan. Perlu dijelaskan kembali bahwa wewenang itu melekat pada jabatan, tetapi dalam pelaksanaannya dijalankan oleh manusia selaku wakil atau fungsionaris jabatan. Oleh karenanya dalam menjalankan kewenangan tersebut nantinya akan berimplikasi kepada tanggung jawab yang akan dipikul subjek hukum dalam melakukan segala sesuatu tindakan hukum.

PNS merupakan subjek hukum yang terkait dengan jabatan dan bertindak atas dasar kewenangan, yang dalam menjalankan tindakan hukumnya terikat pada dua jenis norma, yaitu norma pemerintahan (bestuursnorm) dan norma perilaku aparat (gedragsnorm). Norma pemerintahan adalah kaidah-kaidah hukum tertulis dan tidak tertulis yang berlaku dan diterapkan terhadap jabatan pemerintahan, sedangkan norma perilaku merupakan kaidah-kaidah hukum tertulis dan tidak tertulis yangharus diperhatikan dan dipatuhioleh pemangku jabatan. ${ }^{50}$ Parameter untuk menguji norma pemerintahan adalah asas legalitas, asas spesialitas dan AAUPB, sedangkan parameter untuk menguji

49 Ridwan H.R, dan Harahap, Hukum Kepegawaian, hlm. 153.

50 Ridwan H.R, “Catatan Ringkas Hukum Kepegawaian”, hlm. 20. 
norma perilaku adalah konsep maladministrasi. ${ }^{51}$

Oknum PNS yang melakukan pungutan liar sesungguhnya telah melakukan maladministrasi. Seperti yang telah dijabarkan sebelumnya, bahwa dalam Pasal 1 butir 3 UU Ombudsman, maladministrasi terkait dengan perilaku atau perbuatan melawan hukum, melampaui wewenang, menggunakan wewenang untuk tujuan lain dari yang menjadi wewenang tersebut, termasuk kelalaian atau pengabaian kewajiban hukum dalam penyelenggaraan pelayanan publik yang dilakukan oleh penyelenggara negara dan pemerintahan, dalam hal ini termasuk PNS yang kemudian menimbulkan kerugian baik materiil maupun imateriil bagi masyarakat.

Selain itu terdapat macam-macam bentuk maladministrasi yang telah dijabarkan sebelumnya. Bentuk maladministrasi ini antara lain adalah deceitful practice, yaitu praktik-praktik kebohongan, tidak jujur terhadap publik. Masyarakat disuguhi informasi yang menjebak, informasi yang tidak sebenarnya, untuk kepentingan birokrat dan korupsi yang terjadi karena penyalahgunaan wewenang yang dimilikinya, termasuk di dalamnya mempergunakan kewenangan untuk tujuan lain dari tujuan pemberian kewenangan dan dengan tindakan tersebut untuk kepentingan memperkaya dirinya, orang lain kelompok maupun korporasi yang merugikan keuangan negara atau merupakan bentuk maladministrasi secara korupsi aktif berupa permintaan imbalan uang atau korupsi, yang dalam proses pemberian pelayanan umum kepada masyarakat, seorang pejabat publik meminta imbalan uang dan sebagainya atas pekerjaan yang sudah semestinya dia lakukan (secara cuma-cuma) karena merupakan tanggung jawabnya. ${ }^{52}$ Selain itu, PNS, sebagaimana diatur pada angka 1 Pasal 4 Peraturan Pemerintah Nomor 53 Tahun 2010 tentang Disiplin PNS, juga dikenai larangan penyalahgunaan wewenang. Hal demikian, seperti yang dibahas sebelumnya, juga termasuk maladministrasi apabila dilakukan PNS.

Pungutan liar sesungguhnya dapat dikategorikan ke dalam bentuk atau macam-macam maldministrasi, karena mengandung

51 Ridwan H.R dan Harahap, Hukum Kepegawaian, hlm. 157.

52 ORI, Memahami Maladministrasi, hlm. 17-18. 
praktik kebohongan terhadap publik dan menyuguhkan informasi yang menjebak sehingga dapat merugikan masyarakat. Ia juga termasuk perbuatan koruptif karena mempergunakan kewenangan untuk tujuan lain dalam hal ini memperkaya diri sendiri. Oleh karena pungutan liar ini merupakan tindakan maladministrasi, maka PNS yang melakukannya berarti telah melanggar norma perilaku. Seperti telah disampaikan sebelumnya, pelanggaran terhadap norma perilaku akan menimbulkan konsekuensi tanggung jawab pribadi, yang berarti akan ditanggung oleh oknum PNS yang melakukannya bukan pada jabatan atau instansi di mana pejabat yang bersangkutan berada. Jika dihubungkan dengan teori tanggung jawab pejabat terkait dengan ganti rugi yang dikemukakan oleh Kranenburg dan Vegtig tentang fautes personalles dan fautes de services, maka kerugian pihak ketiga dibebankan kepada pejabat yang karena tindakannya itu telah menimbulkan kerugian. Dalam teori ini beban tanggung jawab ditujukan pada manusia selaku pribadi, bukan kepada jabatannya.

Sekarang, bagaimana apabila tanggung jawab dalam melaksanakan norma-norma tersebut merujuk pada teori cara memperoleh kewenangan. Sebab, dalam melakukan berbagai macam tindakan hukum dengan memperhatikan norma pemerintahan maupun norma perilaku, PNS mendapat kewenangan dari peraturan perundang-undangan yang harus dipertanggungjawabkan. Telah dibahas sebelumnya bahwa kewenangan diperoleh dengan tiga cara, yaitu atribusi, delegasi, dan mandat. Dalam kasus pungutan liar ini maka apabila nantinya PNS tersebut melakukan pungutan liar dalam pelayanan publik, yang kemudian kewenangannya dalam pelayanan publik ini diperoleh dengan cara atribusi, maka jelas pertanggungjawabannya ada pada penerima wewenang atau dalam hal ini oknum PNS yang melakukan pungli. Hal ini dikarenakan kewenangan tersebut langsung diberikan dan ditujukan oleh paraturan perundang-undangan kepada penerima atribusi. Demikian pula, jika kewenangan tersebut diperoleh dengan cara delegasi yaitu terjadi pelimpahan wewenang dari pejabat yang satu kepada pejabat yang sifatnya horizontal (bukan atasan bawahan), maka tanggung jawabnya secara yuridis tidak lagi berada pada pemberi delegasi 
melainkan beralih pada penerima delegasi, dalam pungutan liar berarti ada pada penerima wewenang atau dalam hal ini oknum PNS yang melakukannya.

Tanggung jawab demikian itu berbeda apabila kewenangan diperoleh dengan mandat. Dalam kewenangan yang berasal dari mandat, yang berarti penerima mandat hanya bertindak untuk dan atas nama pemberi mandat (ada hubungan vertikal yaitu atasan dan bawahan), maka tanggung jawab akhir keputusan tetap berada pada pemberi mandat. Dalam kasus pungutan liar, hal ini berarti yang relevan dikenakan tanggung jawab adalah pemberi mandat (mandans). Namun dalam realitanya, karena operasi tangkap tangan dalam kasus pungli banyak dilakukan seperti pada kasus-kasus yang telah dibahas pada latar belakang masalah, maka yang dikenakan adalah oknum yang melakukan pungli tersebut dan tidak menutup kemungkinan juga apabila kewenangannya diperoleh dengan mandat maka yang memberikan juga dapat dikenakan. Hal demikian juga terkait karena pihak yang memberi mandat atau atasan oknum PNS yang melakukan pungli tersebut seharusnya tetap melakukan pengawasan atau adanya pengawasan atasan langsung kepada oknum PNS tersebut dalam menjalankan tugasnya atau dapat dikatakan permasalahan tersebut bersifat kasuistis. Namun, tentu saja penentuan siapa yang harus memikul tanggung jawab atas kerugian yang muncul akibat penggunaan wewenang harus melalui proses peradilan, ${ }^{53}$ yang kemudian nantinya oknum PNS tersebut dapat diberikan sanksi pidana maupun administratif. ${ }^{54}$

Salah satu contoh mengenai pertanggungjawaban dalam pungli yang dilakukan oleh oknum PNS ini dapat dilihat dari putusan pada perkara pidana di Pengadilan Negeri Medan, yaitu Putusan Nomor 121/Pid.Sus-TPK/2017/PN Mdn dengan terdakwa Indra Fauzi, seorang PNS Golongan III-D di UPT PKB Pinang Baris Medan

53 Ridwan H.R, Hukum Administrasi Negara, hlm. 353.

54 Pasal 6 Peraturan Pemerintah Nomor 53 Tahun 2010: "dengan tidak mengesampingkan ketentuan dalam peraturan pidana, PNS yang melakukan pelanggaran disiplin PNS akan dijatuhi hukuman disiplin dan apabila perbuatan tersebut terdapat unsur pidana maka terhadap PNS tersebut tidak tertutup kemungkinan dapat dikenakan hukuman pidana." 
Dinas Perhubungan Kota Medan yang didakwa telah melakukan tindak pidana korupsi dan melanggar Pasal 11 Jo. Pasal 12 A ayat (1) dan ayat (2) UU RI No. 20 Tahun 2001 tentang Perubahan Atas UU No. 31 Tahun 1999 tentang Pemberatasan Tindak Pidana Korupsi Jo. Pasal 55 ayat (1) ke-1e KUHPidana karena melakukan pungutan liar dalam pengurusan perpanjangan kartu uji berkala kenderaan bermotor atau buku speksi (STUK/KIR) tanpa menghadirkan kendaraan (pengurusan tembak/PT) di UPT PKB Pinang Baris Dinas Perhubungan. Dalam putusan tersebut, hakim memutuskan untuk menjatuhkan pidana dengan pidana penjara selama satu bulan, denda sebesar lima juta rupiah, subsidair 10 hari kurungan. Dari putusan tersebut maka tanggung jawab hukuman pidana berupa kurungan penjara ditanggung oleh pribadi PNS bersangkutan dan hukuman denda juga dibebankan kepada pribadi PNS yang melakukan pungli tersebut. ${ }^{55}$

\section{E. Kesimpulan}

Artikel ini menyimpulkan, pertanggungjawaban PNS sama halnya dengan pertanggungjawaban pemerintah atau pejabat, karena PNS sebagai aparatur negara yang merupakan organ pemerintahan yang dibebani pertanggungjawaban jabatan maupun pribadi. Tanggung jawab jabatan berkenaan dengan keabsahan tindakan hukum pemerintahan yang dilakukan oleh pejabat untuk dan atas nama jabatan (ambtshalve) dan pelanggaran terhadap norma pemerintahan. Berdasarkan keterangan tersebut, maka pemikul tanggung jawab itu adalah jabatan. Oleh karena itu, ganti rugi juga dibebankan kepada instansi/ jabatan, bukan kepada pejabat selaku pribadi. Sedangkan tanggung jawab pribadi berkaitan dengan pelanggaran norma perilaku yang diuji menggunakan maladministrasi dalam penggunaan wewenang maupun public service. Seorang pejabat yang melaksanakan tugas dan kewenangan jabatan atau membuat kebijakan akan dibebani tanggung jawab pribadi jika ia melakukan tindakan maladministrasi.

55 Pengadilan Negeri Medan, Putusan Pengadilan Tindak Pidana Korupsi Nomor 121 / Pid.Sus-TPK/2017/PN Mdn. 
Pungutan liar termasuk dalam kategori perbuatan maladministrasi, oleh karena itu dalam melakukan maladministrasi berarti oknum PNS tersebut telah melakukan pelanggaran terhadap norma perilaku dan akan menimbulkan konsekuensi berupa tanggung jawab pribadi. Dengan demikian, kerugian pihak ketiga karena adanya pungutan liar akan ditanggung oleh oknum PNS yang melakukannya.

\section{Daftar Pustaka}

\section{Artikel/Buku/Laporan}

Abdullah, Rozali. Hukum Kepegawaian. Jakarta: Rajawali, 1986.

Cahyaningrum, Novia, Andre N. Rahmanto, dan Tutik Susilowati.

"Pembinaan Kinerja Pegawai Negeri Sipil di Dinas Pendidikan Kota Surakarta”. Jurnal Informasi dan Komunikasi Administrasi Perkantoran, 2, 2 (2018): 63-78.

Hartini, Sri dan Tedi Sudrajat. Hukum Kepegawaian di Indonesia. Jakarta: Sinar Grafika, edisi kedua, 2017.

Https: / / medan.tribunnews.com/2018/07/11/tim-saber-punglilakukan-ott-di-dinkes-labusel. "Tim Saber Pungli Lakukan OTT di Dinkes Labusel”, 11/7/2018. Diakses 21/7/2018.

Https: / / nasional.kompas.com/ read/2019/02/20/14023991/icwlambatnya-pemecatan-pns-koruptor-akan-ciptakan-budayapermisif. "ICW: Lambatnya Pemecatan PNS Koruptor Akan Ciptakan Budaya Permisif”, 20/2/2019. Diakses 22/ 7 / 2019.

Https: / / news.detik.com/berita/ d-4009243 / pungli-kir-2-pns-dishubdi-riau-kena-ott-tim-saber. "Pungli KIR, 2 PNS Dishub di Riau Kena OTT Tim Saber”, 7/5/2018. Diakses 8/5/2018.

Https: / / www.merdeka.com/peristiwa/ hingga-agustus-2017-92pns-di-jatim-jadi-tersangka-ott-pungli.html. "Hingga Agustus 2017, 92 PNS di Jatim jadi tersangka OTT pungli”, 24/8/2017. Diakses 5/1/2018.

Http:/ / www.rri.co.id/post/berita/519506/nasional/sejak. "Sejak Dibentuk, Satgas Saber Pungli Telah Mengungkap 900 Kasus". Diakses 11/5/2018.

Marbun, S.F. Hukum Administrasi Negara I. Yogyakarta: UII Press, 2012. 
Ombudsman Republik Indonesia (ORI). Memahami Maladministrasi. Jakarta: Ombudsman Republik Indonesia, 2013.

Rakhmawanto, Ajib. "Analisis Model Pembinaan Jabatan Fungsional Analisis Kepegawaian di Badan Kepegawaian Negara". Civil Service: Jurnal Kebijakan dan Manajemen PNS, 10, 1 (2016): 1-14.

Ridwan H.R. "Catatan Ringkas Hukum Kepegawaian”. Materi Perkuliahan pada Perkuliahan Hukum Kepegawaian di Fakultas Hukum Universitas Islam Indonesia, Yogyakarta, 2018.

Ridwan H.R. Diskresi dan Tanggung Jawab Pemerintah. Yogyakarta: FH UII Press, 2014.

Ridwan H.R. Hukum Administrasi di Daerah. Yogyakarta: FH UII Press, 2009.

Ridwan H.R. Hukum Administrasi Negara. Jakarta: Rajawali Pers, cetakan kedua belas, 2016.

Ridwan H.R. dan Nurmalita Ayuningtyas Harahap. Hukum Kepegawaian. Yogyakarta: UII Press, 2018.

Ridwan, Juniarso dan Achmad Sodik Sudrajat. Hukum Administrasi Negara dan Kebijakan Pelayanan Publik. Bandung: Nuansa, 2009.

Sudrajat, Tedi. Hukum Birokrasi Pemerintah Kewenangan dan Jabatan. Jakarta: Sinar Grafika, 2017.

Sudrajat, Tedi. "Perlindungan Hukum atas Biropatologi yang Berimplikasi Maladministrasi: Analisis Tindakan Penundaan Berlarut dalam Proses Perizinan”. Civil Service: Jurnal Kebijakan dan Manajemen PNS, 12, 2 (2018): 173-181.

Saputra, Randy. "Pengaruh Disiplin Kerja, Reward dan Punishment terhadap Kinerja Pegawai (Studi Kasus Direktorat Jenderal Bina Keuangan Daerah Kementerian Dalam Negeri)”. Civil Service: Jurnal Kebijakan dan Manajemen PNS, 10, 2 (2016): 55-69.

Sufriadi. "Tanggung Jawab Jabatan dan Tanggung Jawab Pribadi dalam Penyelenggaraan Pemerintahan di Indonesia”. Jurnal Yuridis, 1, 1 (2014): 57-72. DOI: 10.35586/.v1i1.141

Widodo, Joko. Good Governance. Surabaya: Insan Cendikia, 2001.

\section{Peraturan dan Putusan Hukum}

Republik Indonesia. Undang-Undang Nomor 37 Tahun 2008 tentang 
Ombudsman Republik Indonesia.

Republik Indonesia. Undang-Undang Nomor 25 Tahun 2009 tentang Pelayanan Publik.

Republik Indonesia. Undang-Undang Nomot 5 Tahun 2014 tentang Aparatur Sipil Negara.

Republik Indonesia. Peraturan Pemerintah Nomor 43 Tahun 1991 tentang Ganti Rugi dan Tata Cara Pelaksanaannya pada Pengadilan Tata Usaha Negara.

Republik Indonesia. Peraturan Pemerintah Nomor 53 Tahun 2010 tentang Disiplin Pegawai Negeri Sipil.

Republik Indonesia. Peraturan Presiden (Perpres) Nomor 87 Tahun 2016 tentang Satuan Tugas Sapu Bersih Pungutan Liar.

Republik Indonesia, Pengadilan Negeri Medan. Putusan Pengadilan Tindak Pidana Korupsi Nomor 121/Pid.Sus-TPK/2017/PN Mdn. 